\title{
Catatan Beberapa Jamur Liar yang Tumbuh di Sekitar Pemukiman Penduduk
}

\author{
Ivan Permana Putra ${ }^{1 *}$, Mira Astuti ${ }^{2)}$ \\ ${ }^{1}$ Divisi Mikologi, Departemen Biologi, Institut Pertanian Bogor \\ ${ }^{*}$ Email: ivanpermanaputra@apps.ipb.ac.id \\ ${ }^{2}$ Alumni Prodi Pendidikan Biologi, FTMIPA, Universitas Indraprasta PGRI \\ email: miraastuti1003@gmail.com
}
APA Citation: Putra, I.P., \& Astuti, M. (2020) Catatan Beberapa Jamur Liar yang Tumbuh di Sekitar Permukiman Penduduk. Quagga: Jurnal Pendidikan dan Biologi, 13(1),48-59. doi: 10.25134/quagga.v13i1.3617.

Received: 07-11-2020

Accepted: 03-12-2020

Published: 01-01-2021

\begin{abstract}
Abstrak: Jamur merupakan organisme yang memiliki sebaran luas dengan rentang ekologi beragam. Keragaman dan potensi jamur liar yang tumbuh di sekitar pemukiman penduduk jarang dilaporkan sebelumnya di Indonesia. Tujuan dari penelitian ini adalah untuk menambah koleksi informasi keragaman jamur liar di tempat-tempat yang bersinggungan dengan kegiatan antropogenik. Eksplorasi jamur dilakukan dengan opportunistic sampling method. Identifikasi jamur dilakukan dengan menggunakan beberapa kunci identifikasi. Sejumlah 10 jamur berhasil diidentifikasi dan dideskripsikan pada penelitian ini. Seluruh jamur tersebut merupakan bagian dari filum Basidiomycota yang terbagi ke dalam 5 ordo dan 8 famili. Jamur-jamur tersebut adalah: Leucoagaricus sp., Marasmiellus sp., Coprinellus sp., Psathyrell asp., Schizophyllum sp., Auricularia sp., Phallusi ndusiatus, Phallus cf. multicolor, Pycnoporus cf. sanguineus, dan Dacryopinax spathularia. Beberapa jamur diketahui memiliki potensi sebagai bahan pangan, obat, dan pewarna alami.
\end{abstract}

Kata kunci : Jamur, Ragam, Potensi, Pemukiman, Indonesia

\begin{abstract}
Fungi are knownto have bothbroad distribution and ecological range. The diversity of wild mushrooms which distributed around the residence area are rarely been reported previously in Indonesia. The purpose of this study is to increase the collection data of the diversity of wild macrofungi in places that intersect with the anthropogenic activities. Observations were conducted usingopportunistic sampling method. The identification of mushrooms was carried out using several identification keys. A total of 10 mushrooms were identified and described in this study. All these fungi are members of the phylum of Basidiomycota which is divided into 5 orders and 8 families. These fungi are: Leucoagaricus sp., Marasmiellus sp., Coprinellus sp., Psathyrella sp., Schizophyllum sp., Auricularia sp., Phallus indusiatus, Phallus cf. multicolor, Pycnoporus cf. sanguineus, and Dacryopinax spathularia. Some mushrooms are known to have potential as food, medicinal, and natural dyes.
\end{abstract}

Keywords: Mushrooms, Variety, Potency, Residence, Indonesia

\section{PENDAHULUAN}

Jamur merupakan kelompok cendawan dengan tubuh buah/basidioma dengan ukuran besar dan bisa dilihat dengan mata tanpa alat bantu khusus. Organisme ini bersifat heterotrof sehingga bergantung pada ketersediaan bahan organik yang ada di lingkungan. Sebagian besar kelompok fungi dengan tubuh buah yang besar merupakan anggota dari filum Basidiomycota, dan sedikit dari Ascomycota yang maskroskopik (Hawksworth 2001).

Karena sifatnya yang kosmopolitan, jamur mampu tumbuh dan menginvasi berbagai macam habitat. Berdasarkan perangkat kolonisasi yang dimilikinya, ditambah gaya hidup yang beragam (saprofit, parasit, mikoriza), membuat jamur bisa ditemukan mulai dari ekosistem alami ataupun ekosistem buatan manusia (Putra et al. 2017; 2018; 2019a; 2019b; Putra, 2020a; 2020b; 2020c; 2020d; Putra dan Khafazallah 2020). Lembaga Ilmu Pengetahuan Indonesia/LIPI pada tahun 2019 melaporkan bahwa hingga tahun 2017, baru tercatat sebanyak 2273 jenis jamur (makro dan mikro) di Indonesia, atau hanya $0.15 \%$ dari ragam yang ada di Dunia. Data ini seharusnya lebih banyak dari yang ada saat ini, karena daerah tropis memiliki diversitas yang tinggi.

Salah satu tempat yang belum banyak dilaporkan ragam jamurnya di Indonesia adalah daerah sekitaran pemukiman penduduk ataupun tempat-tempat yang bersinggungan dengan aktivitas manusia. Hingga saat ini hanya ditemukan sedikit laporan mengenai ragam dan 
Quagga: Jurnal Pendidikan dan Biologi

Volume 13, Nomor1, Januari 2021, pp.48-59
p-ISSN 1907-3089, e-ISSN2651-5869

https://journal.uniku.ac.id/index.php/quagga potensi jamur di wilayah-wilayah tersebut di Indonesia (Putra et al. 2018; Putra 2020a; 2020b; 2020c; Khastini et al. 2018; 2019). Pemukiman penduduk di sekitar Bojong Gede, Bogor, Jawa Barat meruapakan salah satu lokasi dengan data ragam jamur yang belum pernah dilaporkan sebelumnya. Daerah ini memiliki curah hujan yang tinggi dan memiliki hutan kota di sekitar pemukiman penduduk. Dengan kondisi kelembapan yang baik dan tersedianya berbagai macam bahan organik, tempat ini merupakan salah satu kandidat yang baik untuk mempelajari urban mushroom di Indonesia.Tujuan dari penelitian ini adalah menyediakan informasi keragaman dan potensi jamur guna pemanfaatannya di masa mendatang.

\section{METODOLOGI PENELITIAN}

Pengumpulan data dilakukan pada bulan Agustus-Oktober 2020 di daerah pemukiman penduduk Kecamatan Bojonggede, Bogor, Jawa Barat. Eksplorasi jamur dilakukan dengan opportunistic sampling method merujuk pada penjelasan Prayudi et al. (2019). Deskripsi jamur dilakukan dengan menggunakan karakter makroskopik dengan merujuk pada deskripsi Putra et al. (2018). Parameter makroskopikyang dicatat meliputi cara tumbuh, bentuk tubuh buah, hygrophanous, warna tudung (cap) ketika tubuh buah muda dan tua, diameter cap,bentuk atas dan bawah pada cap, permukaan cap, tepian cap, margin cap, tingkat kebasahan, tipe himenofor (lamela, pori, gerigi) meliputi : cara menempel pada stipe, panjang, jarak antar baris, dan margin. Karakter lain yang diobservasi adalah bentuk stipe, warna stipe (ketika muda dan tua), permukaan stipe, posisi penempelan pada cap,tipe penempelan stipe pada substrat, penampang stipe, partial veil dan universal veil, tekstur tubuh buah, bau, rasa serta informasi penggunaannya sebagai bahan pangan (edible atau non edible) melalui studi literatur untuk mendapatkan informasi mengenai pemanfaatan jamur yang ditemukan. Jamur diidentifikasi hingga ke tingkat genus dan spesies dengan menggunakan beberapa acuan identifikasi diantaranya Arora (1986), Rokuya et al.(2011), Desjardin et al. (2016), dan Putra \&Khafazallah (2020). Pemberian nama hingga ke level spesies diberikan penanda cf (confer) yang merujuk kepada karakter terdekat jamur yang diidentifikasi pada identitas taksonomi tertentu. Acuan klasifikasi mengikuti Hibbett et al. (2007) dan aturan indexfungorum.

\section{HASIL DAN PEMBAHASAN}

Sebanyak 10 jamur berhasil diidentifikasi dan dipertelakan pada tulisan ini. Seluruh jamur tersebut merupakan bagian filum Basidiomycota yang terbagi ke dalam 5 ordo dan 8 famili (Tabel 1). Jamur-jamur tersebut adalah: Leucoagaricus sp., Marasmiellus sp., Coprinellus sp., Psathyrella sp., Schizophyllum sp., Auricularia sp., Phallus indusiatus, Phallus cf. multicolor, Pycnoporus cf. sanguineus, dan Dacryopinax spathularia. Masing-masing jamur memiliki karakteristik yang berbedabeda. Tulisan ini merupakan sedikit dari laporan mengenai keragaman jamur yang tumbuh di sekitaran pemukiman penduduk di Indonesia. Berikut merupakan jamur yang dipertelakan beserta informasi terkait lainnya.

Tabel 1. Posisi taksonomi jamur-jamur yang dipertelakan pada penelitian ini

\begin{tabular}{|c|c|c|c|c|}
\hline Filum & Kelas & Ordo & Famili & Spesies \\
\hline \multirow[t]{9}{*}{ Basidiomycota } & Agaricomycetes & Agaricales & Agaricaceae & Leucoagaricus sp. \\
\hline & & & Omphalotaceae & Marasmiellus sp. \\
\hline & & & Psathyrellaceae & Coprinopsis sp. \\
\hline & & & & Psathyrella sp. \\
\hline & & & Schizophyllaceae & Schizophyllum sp. \\
\hline & & Auriculariales & Auriculariaceae & Auricularia sp. \\
\hline & & Phallales & Phallaceae & $\begin{array}{l}\text { Phallus indusiatus } \\
\text { Phallus cf. multicolor }\end{array}$ \\
\hline & & Polyporales & Polyporaceae & Pycnoporus cf. sanguineus \\
\hline & Dacrymycetes & Dacrymycetales & Dacrymycetaceae & Dacryopinax spathularia \\
\hline
\end{tabular}


Quagga: Jurnal Pendidikan dan Biologi

Volume 13, Nomor1, Januari 2021, pp.48-59
p-ISSN 1907-3089, e-ISSN2651-5869

https://journal.uniku.ac.id/index.php/quagga

\section{Leucoagaricus sp.}

Jamur ini tumbuh berkelompok dalam jumlah terbatas pada tanah berhumus dengan banyak alang-alang di sekitarnya (Gambar 2A). Jamur ini memiliki bentuk tubuh buah berupa tudung (cap/pileus) berlamela dan bertangkai (stipe). Tudung berwarna putih hingga krem dengan variasi warna coklat terang berupa benang-benang pada beberapa bagian. Tudung berbentuk setengah mangkuk terbalik hingga conic pada fase muda dan dewasa, permukaan fibrillose (Gambar 2D).Tepian tudung rata dengan margin sedikit bergelombang. Tipe himenofor jamur ini berupa lamela yang berwarna putih-krem (Gambar 2C) yang membedakan kelompok ini dengan Agaricus, lamela tidak menempel pada stipe (bebas/free) (Gambar 2C), jarak antar baris medium, dan margin rata (entire). Stipe berbentuk silindris berwarna putih, dilengkapi cincin pada posisi superior, permukaan tangkai dengan serabut halus, menempel ke tudung pada posisicentral, dan bagian basal dari tangkai yang membentuk rizomorf yang jelas. Tekstur tubuh buahnya berdaging tanpa bau yang khas.

Hingga saat ini tercatat sebanyak 305 spesies, subspesies, dan varietas dari Leucoagaricus di seluruh dunia (http://www.indexfungorum.org/Names/Names .asp, diakses pada 01 Agustus 2020). Penelitian Leuocoagaricus telah banyak dilakukan di kawasan empat musim (Muñoz et al. 2012; Aron 2014), namun mikologiwan meyakini bahwa ragam dari kelompok ini lebih banyak berada di daerah tropis, walaupun dokumentasinya belum dillakukan dengan baik (Vellinga 2004). Leucoagaricus seringkali ditemukan di sekitar perumahan, rerumputan, ataupun tempat-tempat yang bersinggungan dengan kegiatan antropogenik (Muñoz et al. 2012). Beberapa penelitian melaporkan potensi dari Leucoagaricus sebagai agen remediasi limbah pewarna (Ning et al. 2016) dan $L$. leucothites sebagai bahan pangan karena memiliki kandungan antioksidan yang tinggi (Sevindik et al. 2018).

\section{Marasmiellus sp.}

Jamur ini tumbuh soliter ataupun berkelompok dalam jumlah banyak pada serasah kayu yang bercampur tanah (Gambar 3A). Jamur ini memiliki bentuk tubuh buah berupa tudung (cap/pileus) berlamela dan bertangkai (stipe). Tudung berwarna putih cerah hingga krem kecoklatan. Tudung berbentuk setengah mangkuk terbalik hingga ratadengan gurat pada lingkaran tudugnya (Gambar 3A).Tepian tudung rata dengan margin sedikit bergelombang (Gambar 3B;C). Jamur ini memiliki himenofor berupa lamela yang berwarna putih-krem (Gambar 3B;C;D), lamela menempel sempit pada tangkai dengan struturcollar (Gambar 3B;D), jarak antar baris jauh/distant dengan 1-2 lamellulae di antara 2 lamela (Gambar 3C), dan margin lamela rata (entire). Tangkai berbentuk silindris berwarna krem pada bagian atas dan krem keunguan pada setengah bagian bawahnya (Gambar 3B), tanpa cincin, keras, permukaan tangkai halus, menempel ke tudung pada posisi central, dan bagian basal menempel langsung pada substrat.Tekstur tubuh buahnya berdaging tanpa bau yang khas.

Hingga saat ini tercatat sebanyak 484 spesies, subspesies, dan varietas dari Marasmiellus di seluruh dunia (http://www.indexfungorum.org/Names/Names .asp, diakses pada 01 Agustus 2020). Di Indonesia, laporan yang lengkap mengenai keberadaan Marasmiellus dilaporkan oleh Retnowati (2018), dengan 35 spesies dilaporkan dari Pulau Jawa dan Bali, dan 16 diantaranya merupakan spesies baru. Beberapa jenis dari jamur ini bisa dimanfaatkan sebagai bahan pangan di Indonesia, seperti $M$. ramealis (Fitra et al. 2020). 


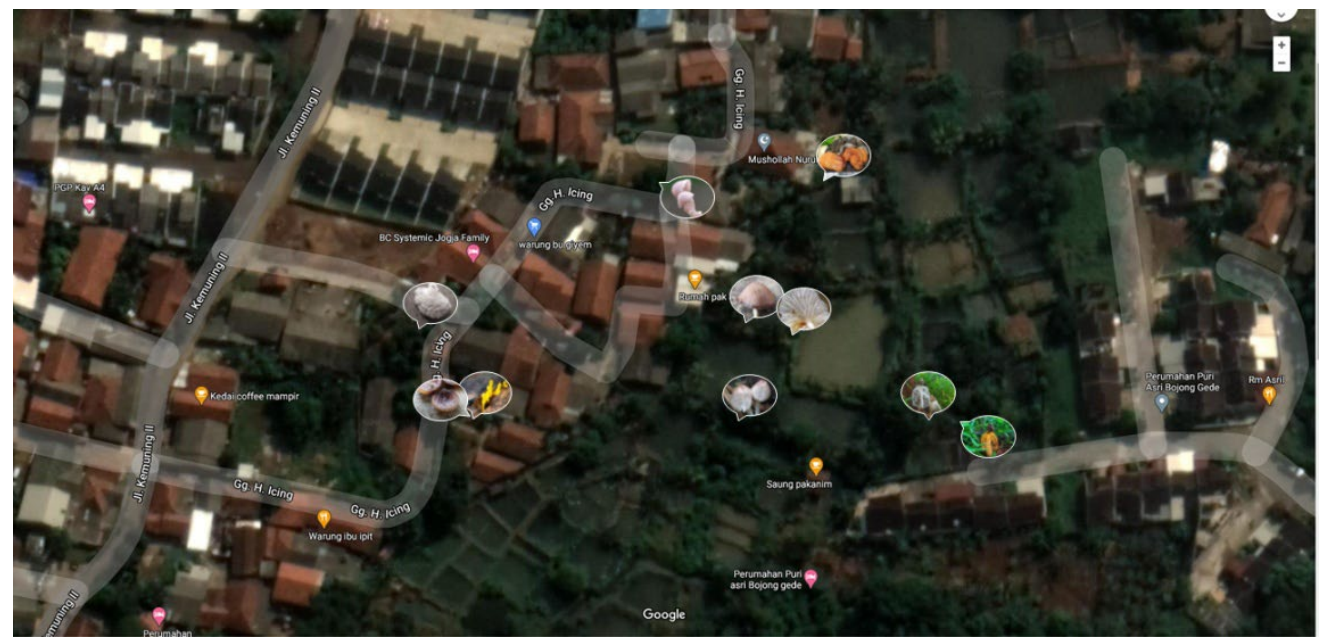

Gambar 1. Lokasi pengamatan jamur. (Sumber : diolah dari google earth)

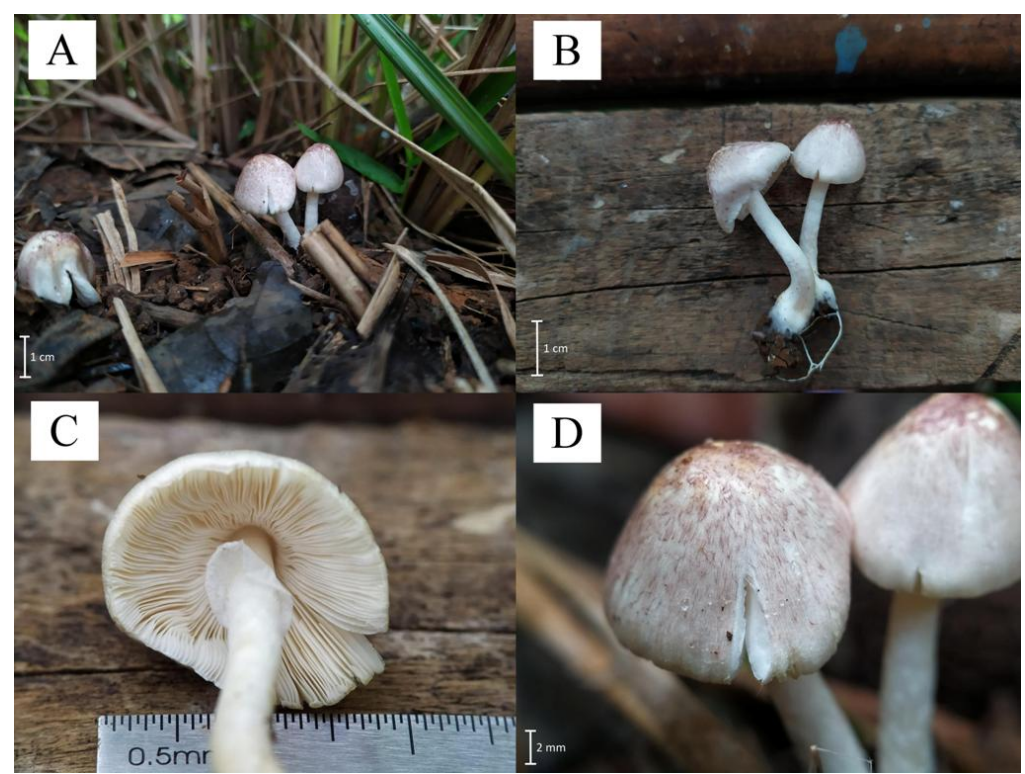

Gambar 2. Karakter identifikasi makroskopis Leucoagaricus sp.

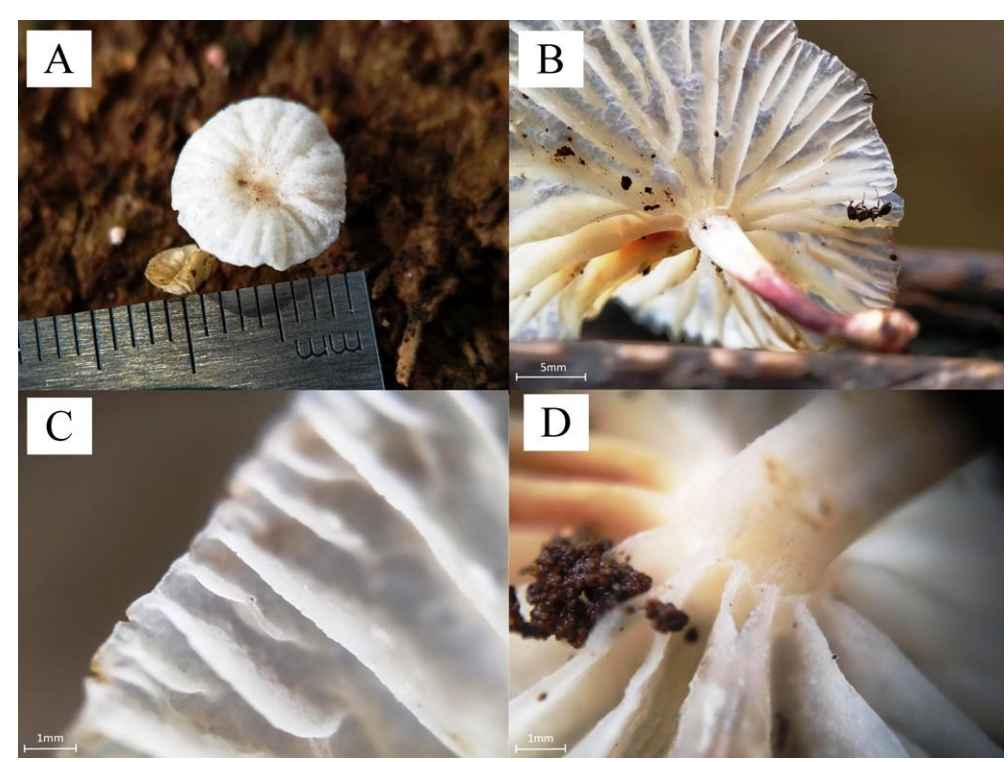

Gambar 3. Karakter identifikasi makroskopis Marasmiellus sp. 
Quagga: Jurnal Pendidikan dan Biologi

Volume 13, Nomor1, Januari 2021, pp.48-59
p-ISSN 1907-3089, e-ISSN2651-5869

https://journal.uniku.ac.id/index.php/quagga

\section{Coprinopsis sp.}

Jamur ini tumbuh berkelompok pada tanah berhumus (Gambar 4A) dengan buah berdekatan. Jamur ini memiliki bentuk tubuh buah berupa tudung (cap/pileus) berlamela dan bertangkai (stipe). Tudung berwarna coklat gelap, berbentuk convex (Gambar 4A), permukaan halus dengan guratan fibril dengan jarak teratur. Tepian tudung rata dengan margin sedikit bergelombang (Gambar 4D). Jamur ini memiliki himenofor berupa lamela dengan warna yang sama dengan permukaan tudung (4C), eksudat hitam merupakan luruhan spora yang terkena air hujan saat eksplorasi dilakukan, lamela menempel pada tangkai dengan tipe free (Gambar 4C), jarak antar baris medium, dan margin lamela rata (entire). Tangkai berbentuk silindris berwarna putih hingga krem (Gambar 4B), tanpa cincin, berongga, permukaan halus, menempel ke tudung pada posisi central, dan bagian basal menempel langsung pada substrat. Tekstur tubuh buahnya berdaging tanpa bau yang khas.

Hingga saat ini tercatat sebanyak 201 spesies, subspesies, dan varietas dari Coprinopsis di seluruh dunia (http://www.indexfungorum.org/Names/Names .asp, diakses pada 01 Agustus 2020). Genus ini merupakan kelompok yang sangat berkerabat dekat dengan Coprinus, Coprinellus, dan Parasola sehingga identitas hingga ke level spesies membutuhkan observasi mikroskopik dan atau molekuler (Gierczyk et al. 2017). Jenis dari kelompok jamur ini yaitu $C$. atramentaria dilaporkan memiliki aktivitas antimikroba dengan kandungan asam fenolat yang baik untuk tubuh (Heleno et al. 2014).

\section{Psathyrella sp.}

Jamur ini tumbuh berkelompok dalam jumlah banyak dengan tubuh buah berlekatan pada bagian basal (Gambar 5D) di bongkahan kayu kelapa yang lapuk (Gambar 5A). Jamur ini memiliki bentuk tubuh buahberupa tudung (cap/pileus) berlamela dan bertangkai (stipe). Tudung berwarna krem kecoklatan, berbentuk convex hingga conic (Gambar 5A;D), permukaan halus dengan sedikit tepung. Tepian tudung rata dengan margin sedikit bergelombang. Jamur ini memiliki himenofo rberupa lamela yang berwarna krem kecoklatan, lamela menempel pada tangkai dengan tipe free (Gambar 5B), jarak antar baris medium, dan margin lamela rata (entire). Tangkai berbentuk silindrisberwarnaputih, tanpa cincin, berongga (Gambar 5C), permukaan halus hingga bertepung, menempel ke tudung pada posisi central, dan bagian basal menempel langsung pada substrat. Tekstur tubuh buahnya berdaging tanpa bau yang khas.

Kelompok jamur ini merupakan organisme yang bergaya hidup saprofit dan tersebar pada berbagai tipe ekosistem alami ataupun buatan (Sicoli et al. 2019). Hingga saat ini tercatat sebanyak 1059 spesies, subspesies, dan varietas dari Psathyrella di seluruh dunia (http://www.indexfungorum.org/Names/Names .asp, diakses pada 01 Agustus 2020) dan merupakan salah satu kelompok jamur yang kompleks. Ribeiro et al. (2017) melaporkan aktivitas sitotoksik dari $P$. asperospora terhadap sel manusia secara in vitro, namun $\mathrm{Al}$ Habib et al. (2018) juga melaporkan potensi dari jenis lain yakni $P$. candolleana berpotensi dimanfaatkan sebagai agen anti kerusakan DNA pada pasien kemoterapi kanker.

\section{Schizophyllum sp.}

Jamur ini tumbuh soliter atau berkelompok dalam jumlah terbatas sebagai saprofit pada kayu rambutan yang telah mati (Gambar 6A). Jamur ini memiliki bentuk tubuh buah berupa tudung (cap/pileus), berlamela dan bertangkai semu (pseudostipe). Tudung berwarna abu-abu, berbentuk kipas (Gambar 6A;B), permukaan berambut (hairy). Tepian tudung bergerigi dengan margin rata. Jamur ini memiliki himenofor berupa lamella, berwarna coklat (Gambar 6B), jarak antar baris medium, dan margin lamela rata (entire). Tangkai semu dengan posisi penempelan pada bagian lateral dari tudung. Tekstur tubuh buahnya berdaging tanpa bau yangkhas.

Jamur ini mudah ditemukan di sekitar pemukiman penduduk. Umumnya, jamur ini tumbuh secara bergerombol dengan ukuran tubuh buah bervariasi pada bongkahan kayu mati. Hingga saat ini tercatat sebanyak 32 spesies, subspesies, dan varietas dari Schizophyllum di seluruh dunia (http://www.indexfungorum.org/Names/Names .asp, diakses pada 01 Agustus 2020). Jenis dari Schizophyllum yang paling banyak dimanfaatkan oleh masyarakat Indonesia sebagai bahan pangan adalah $S$. commune (Putra dan Khafazallah 2020). Jamur ini 
Quagga: Jurnal Pendidikan dan Biologi

Volume 13, Nomor1, Januari 2021, pp.48-59
p-ISSN 1907-3089, e-ISSN2651-5869

https://journal.uniku.ac.id/index.php/quagga

memiliki nama lokal yakni 'kulat rigit' (Sumatra), 'kulat/jamur gerigit' (Sumatra dan Jawa), dan kulat kritip (Kalimantan).

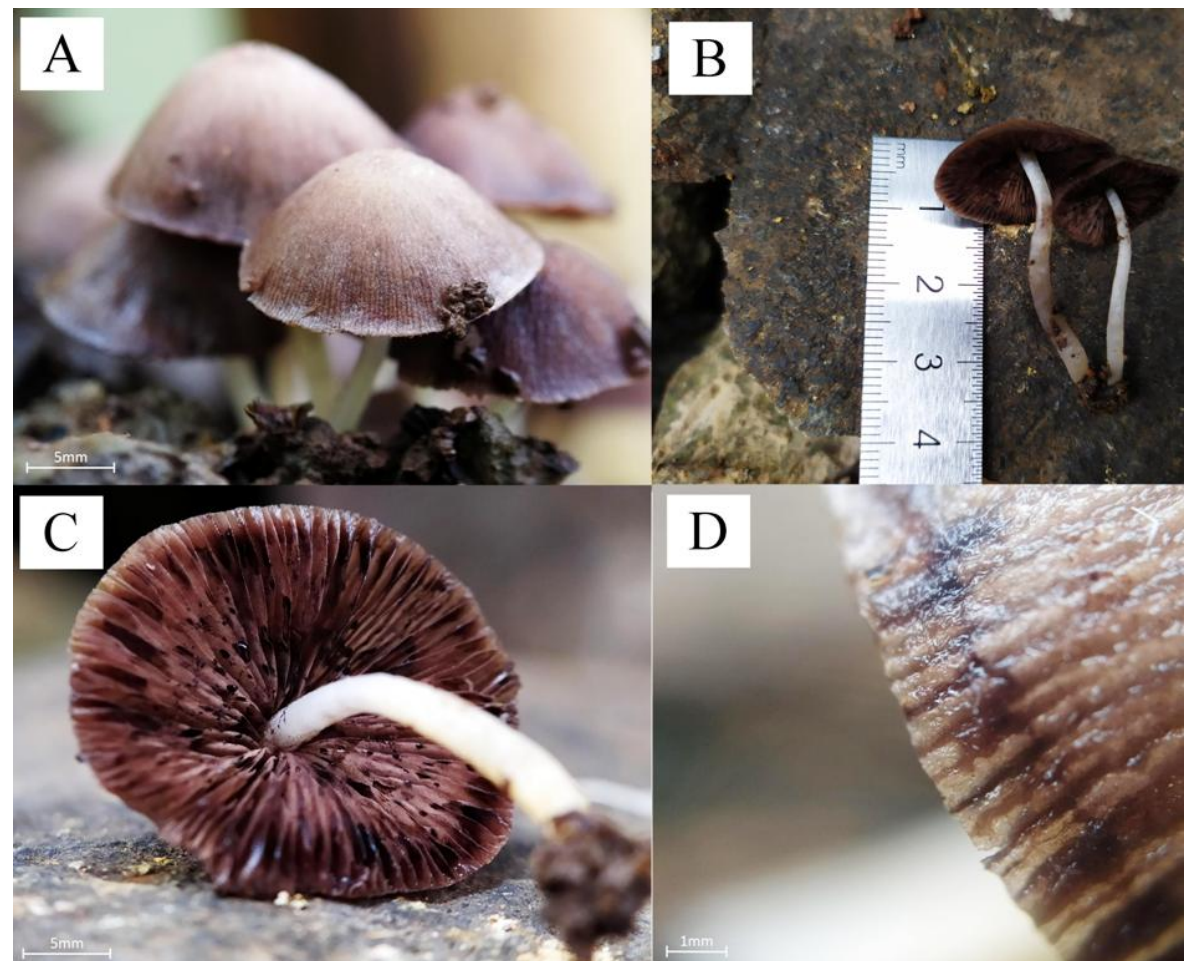

Gambar 4. Karakter identifikasi makroskopis Coprinopsis sp.

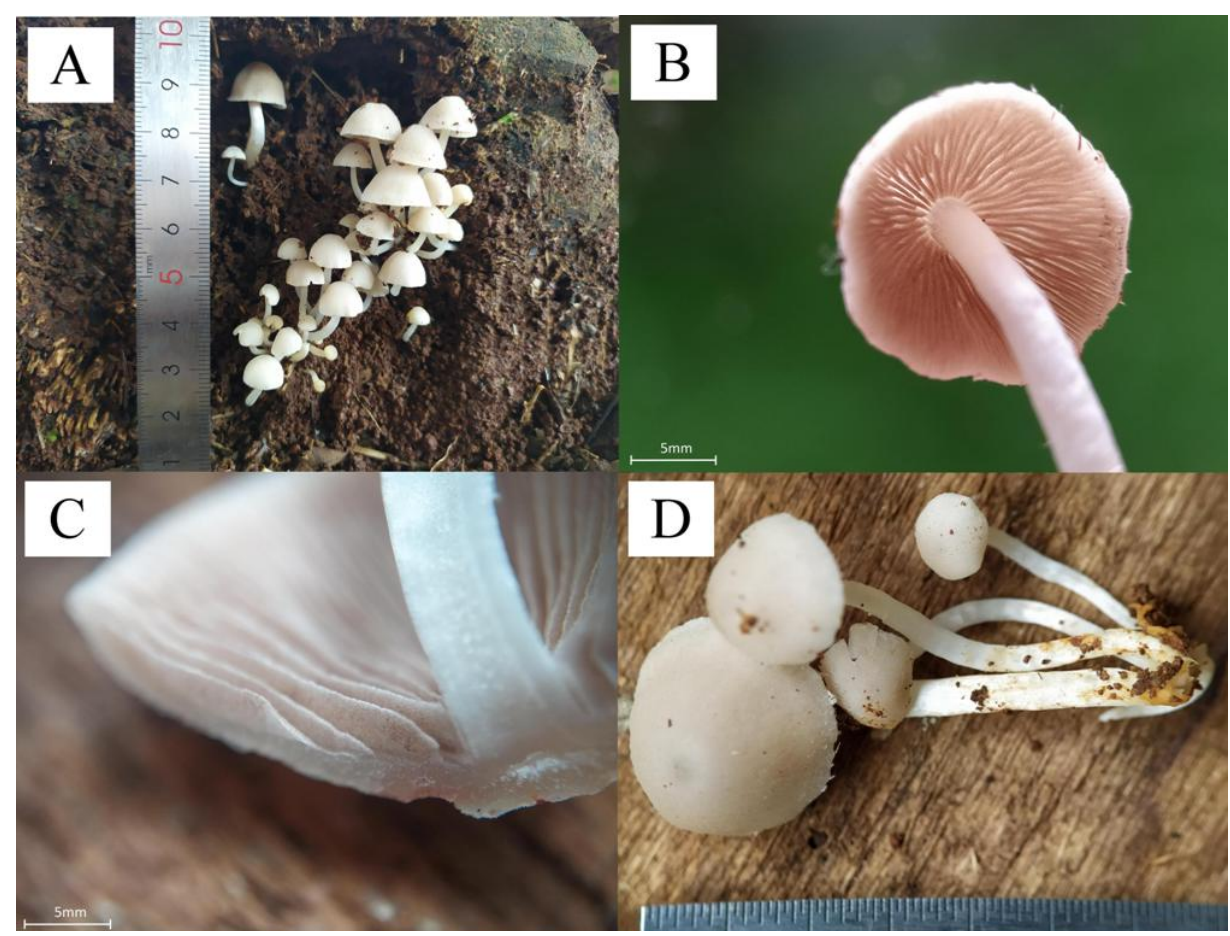

Gambar 5. Karakter identifikasi makroskopis Psathyrella sp. 
Quagga: Jurnal Pendidikan dan Biologi

Volume 13, Nomor1, Januari 2021, pp.48-59
p-ISSN 1907-3089, e-ISSN2651-5869

https://journal.uniku.ac.id/index.php/quagga

\section{Auricularia sp.}

Jamur ini tumbuh berkelompok pada kayu rambutan yang telah mati (Gambar 7A). Jamur ini memiliki bentuk tubuh buah berupa tudung (cap/pileus) dan tanpa tangkai. Tudung berbentuk bulat hingga tidak beraturan dengan bagian atas berwarnacoklat gelap (Gambar 7A). Salah satu bagian tudung yang lebih kasar memiliki benang-benag halus pada permukaannya (Gambar 7B). Tepian tudung lurus dengan margin rata. Spora diproduksi pada bagian halus dari tubuh buah.Tekstur tubuh buahnya kenyal, memiliki lekukan pada kedua permukaannya, dan tanpa bau yang khas.

Hingga saat ini tercatat sebanyak 177 spesies, subspesies, dan varietas dari Auricularia di seluruh dunia (http://www.indexfungorum.org/Names/Names asp, diakses pada 01 Agustus 2020). Auricularia atau yang lebih dikenal sebagai jamur kuping merupakan salah satu jamur yang populer di Indonesia dan dimanfaatkan sebagai bahan pangan. Namun hingga saat ini hanya jamur kuping hasil budidaya yang banyak di konsumsi oleh masyarakat, padahal jamur ini juga mudah ditemukan di sekitar tempat tinggal dan tersebar pada berbagai macam ekosistem (Putra dan Khafazallah 2020). Sekara et al. (2015) melaporkan bahwa banyak spesies dari jamur kuping memiliki kandungan bahan bioaktif yang baik untuk kesehatan sehingga disarankan untuk mengkonsumsinya.

\section{Phallus indusiatus}

Jamur ini tumbuh soliter atau berkelompok dengan jumlah terbatas di tanah gembur dengan banyak ilalang di sekitarnya (Gambar 8A). Jamur ini memiliki bentuk tubuh buah berupa tudung (cap/pileus) yang menyerupai topi melonjong, memiliki tangkai, dan kerudung (veil). Tudung memiliki ornamen/kerutan beraturan dengan eksudat coklat hingga kehitaman pada seluruh bagiannya. (Gambar 8B). Tangkai tumbuh dari bagian telur, berbentuk silinder dengan bagian basal yang lebih besar, berwarna putih, dan dengan tekstur rapuh. Indusium hampir menyentuh tanah, berwarna putih, dengan bulatan angular yang teratur paa seluruh bagiannya.Tekstur tubuh buah jamur ini berdaging dan dengan bau yang menyengat. Jamur ini memiliki siklus tubuh buah yang singkat mulai saat muncul, mekarnya tudung, hingga meluruh dan hilang (Putra dan Khafazallah 2020). Umumnya, jamur ini mudah ditemukan pada daerah yang mengalami gangguan seperti tanah terbakar, serasah bambu, hingga lantai hutan (Cabral et al. 2019). Jamur ini memiliki eksudat tersebut merupakan atraktan serangga dan merupakan salah satu strategi pemencaran spora. Hingga saat ini tercatat sebanyak 181 spesies, subspesies, dan varietas dari Phallus di seluruh dunia (http://www.indexfungorum.org/Names/Names .asp, diakses pada 01 Agustus 2020). Jamur ini sebelumnya telah beberapa kali dilaporkan sebagai jamur edible dengan bermacam manfaat, salah satunya yang terbaru oleh Habtemariam (2019). Namun, karena masih banyaknya perdebatan aspek edibilitas dari jamur ini, jamur ini tidak disarankan untuk dikonsumsi jika belum memiliki pengetahuan dan pengalaman empiris yang baik.

\section{Phallus cf. multicolor}

Jamur ini tumbuh soliter di tanah berhumus dengan banyak serasah dan ilalang di sekitarnya (Gambar 9A). Tubuh buah berupa tudung (cap/pileus) yang menyerupai topi melonjong, memiliki tangkai (stipe), dan kerudung (veil). Tudung memiliki ornamen/kerutan beraturan dengan eksudat coklat hingga kehitaman pada seluruh bagiannya. Tangkai tumbuh dari bagian telur (Gambar 9B), berbentuk silinder yang mengecil pada bagian atasnya, berwarna putih hingga krem, dan dengan tekstur rapuh. Indusium tidak menyentuh tanah (setengah dari tinggi tubuh buah), berwarna kuning hingga oranye, dengan bulatan angular yang teratur paa seluruh bagiannya.Tekstur tubuh buah jamur iniberdaging dan dengan bau yangmenyengat.

Sama seperti $P$. indusiatus, jamur ini dikenal sebagai jamur pengantin atau tudung pengantin oeh penggiat jamur di Indonesia (Putra dan Khafazallah 2020). Selain eksudat yang dihasilkan oleh tudung, warna indusium yang cerah juga merupakan salah satu atraktan untuk serangga. Indusium juga merupakan salah satu bagian penting yang dimanfaatkan oleh banyak serangga yang tidak bisa terbang untuk memanjat tubuh buah jamur ini, dan menuju tudung yang mengeluarkan eksudat yang bercampur spora. Mekanisme ini merupakan bagian dari strategi pemencaran 
spora dari jamur ini dan sangat bergantung

pada kehadiran serangga (Cabral et al. 2019).

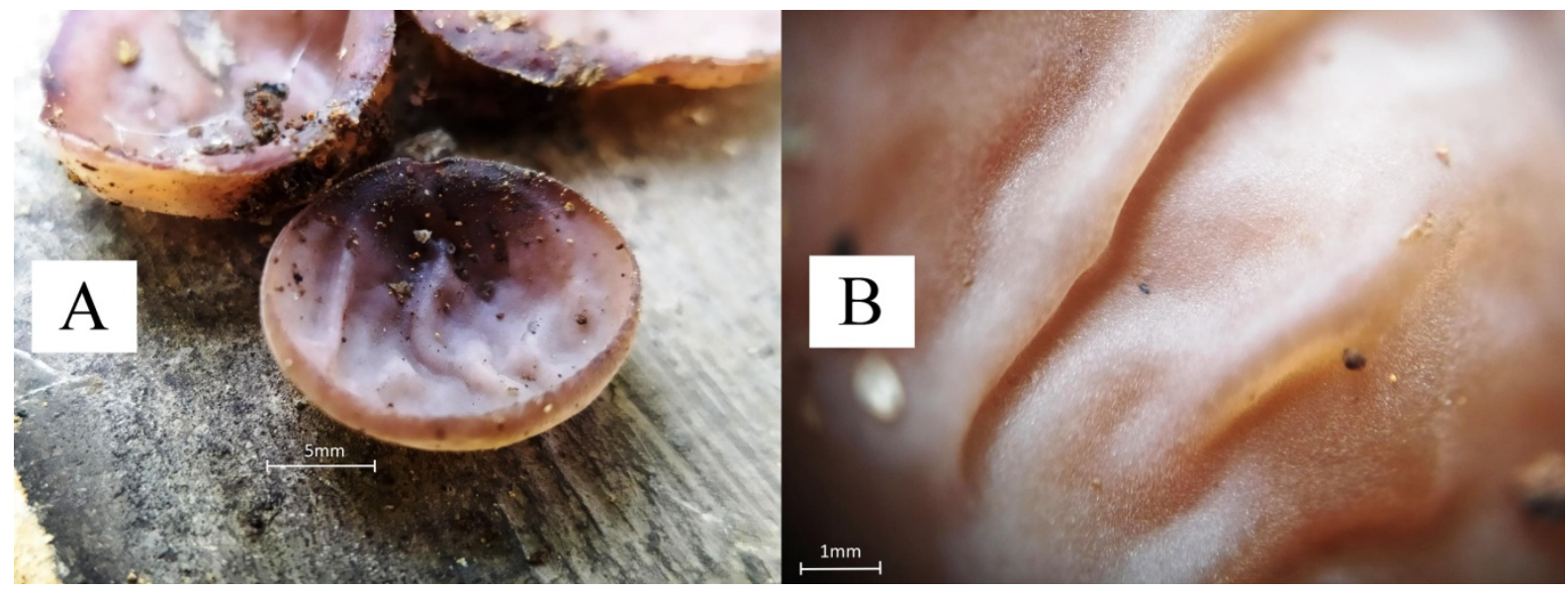

Gambar 7. Karakter identifikasi makroskopis Auricularia sp.

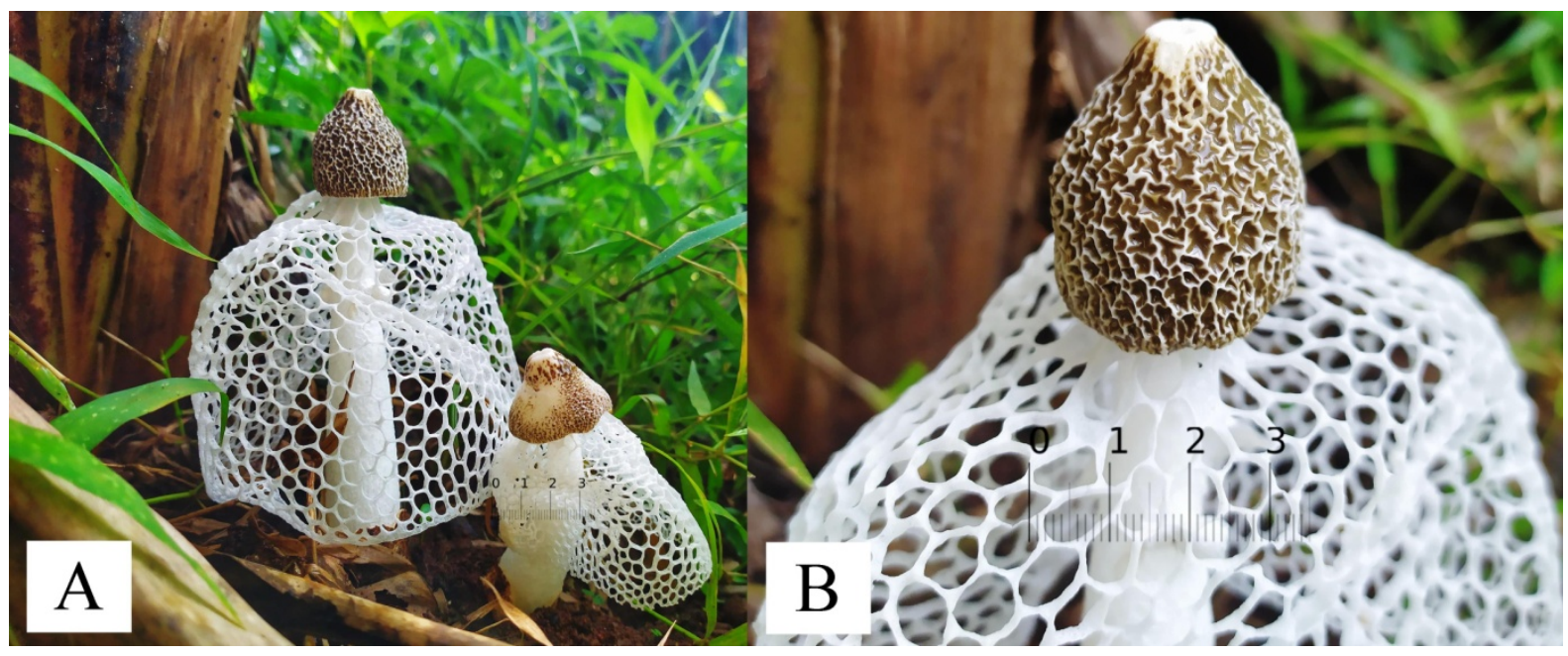

Gambar 8. Karakter identifikasi makroskopis Phallus indusiatus

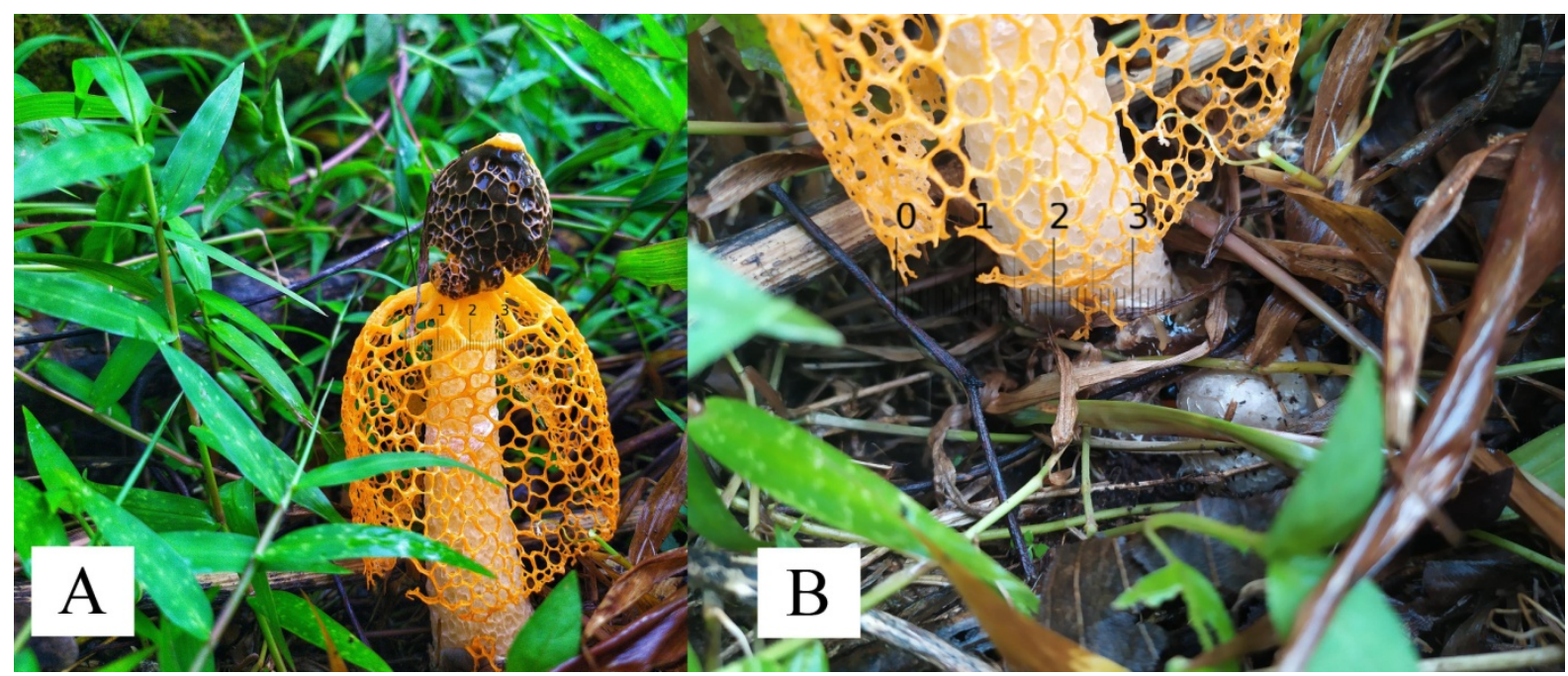

Gambar 9. Karakter identifikasi makroskopis Phallus cf. multicolor 
Quagga: Jurnal Pendidikan dan Biologi

Volume 13, Nomor1, Januari 2021, pp.48-59
p-ISSN 1907-3089, e-ISSN2651-5869

https://journal.uniku.ac.id/index.php/quagga

\section{Pycnoporuscf. sanguineus}

Jamur ini tumbuh berkelompok pada batang kelapa lapuk (Gambar 10A). Jamur ini memiliki bentuk tubuh buahsemi bulat, tanpa tangkai sejati, dan tumbuh sesil.Pileus memiliki lingkaran yang teratur pada seluruh bagiannya. Tudung berwarna oranye dengan warna yang lebih gelap pada bagian yang dekat dengan tangkai semu. Himenofor berbentuk pori dengan warna merah hingga oranye (Gambar 10A;B;C). Pori berbentuk angular dengan perlekatan yang tidak dipisahkan dengan mudah (undetachable) dengan tabung pori rapat (Gambar 10C). Tekstur tubuh buah jamur ini keras dan tanpa bau khas. Ketika dipegang, warna oranye tubuh jamur ini mudah menempel pada tangan.

Jamur ini memiliki persebaran yang luas mulai dari daerah temperate hingga tropis dan memiliki tubuh buah yang mampu bertahan sepanjang tahun (Téllez- Téllez, 2016). Hingga saat ini tercatat sebanyak 13 spesies, subspesies, dan varietas dari Pycnoporus di seluruh dunia (http://www.indexfungorum.org/Names/Names .asp, diakses pada 01 Agustus 2020). Di Indonesia, jamur ini telah dilaporkan dari berbagai habitat mulai dari daerah pemukiman (Iramayana et al. 2019) hingga ekosistem hutan alami (Christita et al. 2017). Pycnoporus memiliki potensi yang baik untuk digunakan sebagai agen bioteknologi mulai dari aspek lingkungan hingga medis (Fazio et al. 2012; Couturier et al. 2015). Karena warnanya yang cerah dan mudah luntur ketika tersentuh atau terpapar air, penulis meyakini bahwa jamur ini berpotensi sebagai salah satu sumber alternatif pewarna alami.

\section{Dacryopinax spathularia}

Jamur ini tumbuh berkelompok pada batang jambu yang lapuk (Gambar 11A). Jamur ini memiliki tekstur kenyal dan berbentuk kipas atau spatula dengan bagian ujung yang membelah dua (dikotom) (Gambar 11A;B). Jamur ini memiliki warna kuning cerah sehingga mudah dikenali. Permukaan tubuh buah memiliki papila kecil dan pada beberapa bagiannya berserabut putih. Himenofor dari berupa lapisan tubuh buah yang licin. Tangkai menempel pada tudung pada posisi samping, licin, berserabut halus pada bagain basalnya, dan memiliki warna yang lebh gelap pada bagian bawahnya.

Hingga saat ini tercatat sebanyak 24 spesies, subspesies, dan varietas dari Dacryopinax di seluruh dunia (http://www.indexfungorum.org/Names/Names .asp, diakses pada 01 Agustus 2020). Putra dan Khafazallah (2020) melaporkan 2 jenis Dacryopinax yakni $D$. spathularia dan $D$. martinii di Indonesia. Jamur ini memiliki potensi sebagai antibakteri untuk beberapa patogen pada manusia (Kumar et al. 2019).

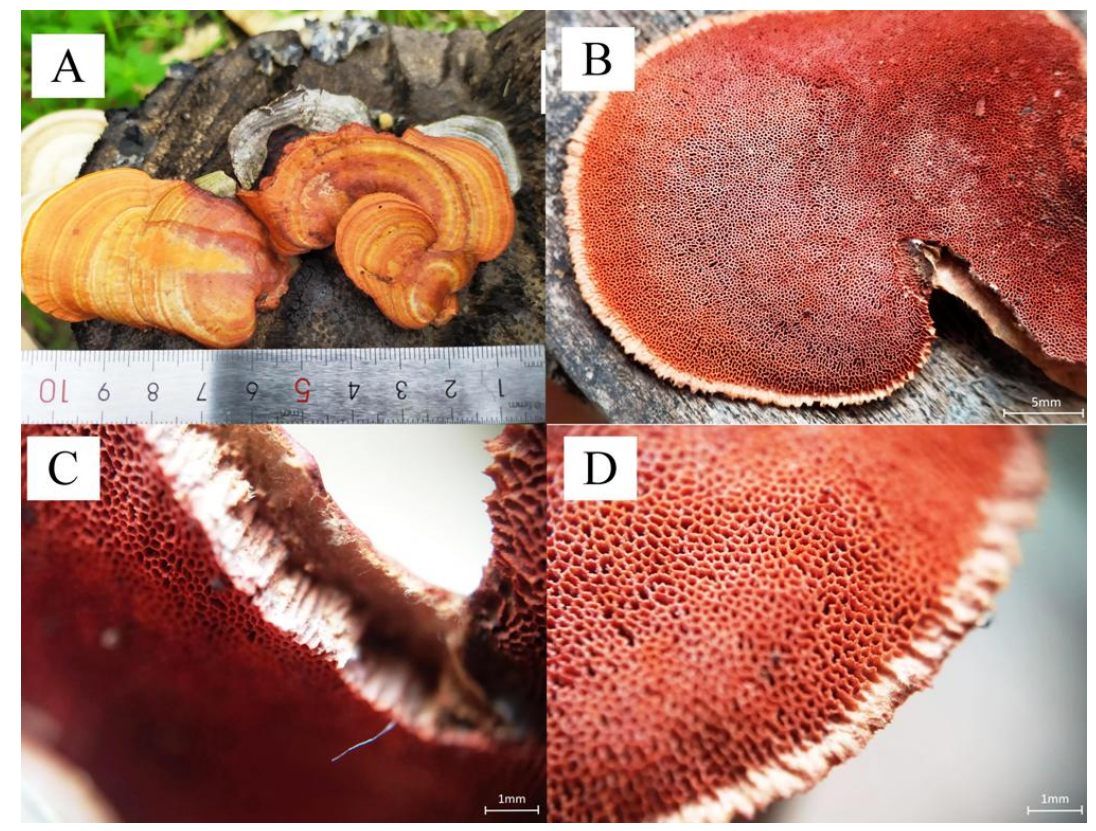

Gambar 10. Karakter identifikasi makroskopis Pycnoporus cf. sanguineus 


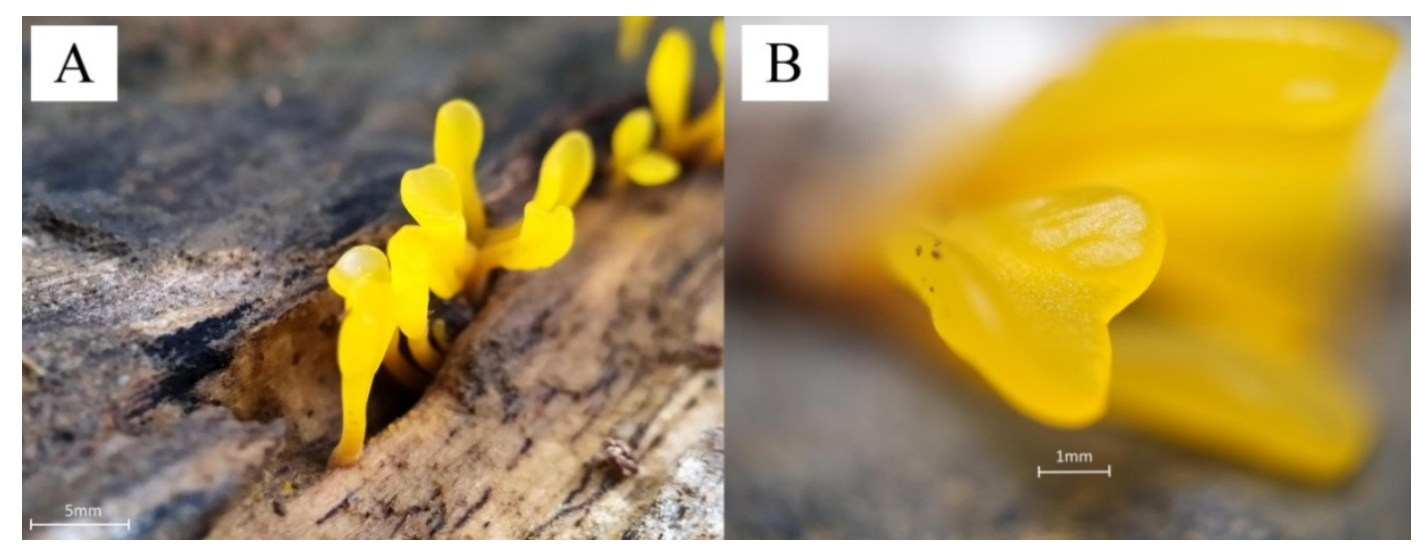

Gambar 11. Karakter identifikasi makroskopis Dacryopinax spathularia

\section{SIMPULAN}

Sebanyak 10 jamur yang tumbuh di sekitar pemukiman penduduk dilaporkan pada penelitian ini. Seluruh jamur tersebut merupakan anggota dari Basidiomycota yang terbagi ke dalam 5 ordo dan 8 famili. Jamurjamur tersebut adalah: Leucoagaricus sp., Marasmiellus sp., Coprinellus sp., Psathyrella sp., Schizophyllum sp., Auricularia sp., Phallus indusiatus, Phallus cf. multicolor, Pycnoporus cf. sanguineus, dan Dacryopinax spathularia. Beberapa jamur memiliki potensi sebagai bahan pangan, obat, dan pewarna alami.

\section{REFERENSI}

Al-Habib, M.N., Holliday, J. \&Aladahmy, M.S. 2018. Psathyrellacandolleana and Agaricusbisporus Extracts Provide Protection against DNA Oxidative Damage Induced by Doxorubicin. International Journal of Medicinal Mushrooms, 20(8), 749-759. http://dx.doi.org/10.1615/intjmedmushro oms.2018027002.

Aron, C. 2014. Leucoagaricus cf. medioflavoides found in Anglesey. Field Mycology, 15(4), 118-120. http://dx.doi.org/10.1016/j.fldmyc.2014. $\underline{09.006 .}$.

Arora, D. 1986. Mushrooms Demystified. USA: Teen Speed Press.

Cabral, T. S., Silva, B. D., Martín, M. P., Clement, C. R., Hosaka, K., \&Baseia, I. G. 2019. Behind the veil - exploring the diversity in Phallus indusiatuss.1. (Phallomycetidae, Basidiomycota). MycoKeys, 58, 103-127. http://dx.doi.org/10.3897/mycokeys.58.3 $\underline{5324}$.
Christita, M., Arini, D., Kinho, J., Halawane, J., Kafiar, J., \&Diwi, M. 2017. Keragaman dan PotensiMakrofungi di ObyekEkowisata Kaki Dian, GunungKlabat-Minahasa Utara. JurnalMikologi Indonesia, 1(2), 82. http://dx.doi.org/10.46638/jmi.v1i2.22.

Couturier, M., Navarro, D., Chevret, D., Henrissat, B., Piumi, F., Ruiz-Dueñas, F. J.,Rosso, M.-N. 2015. Enhanced degradation of softwood versus hardwood by the white-rot fungus Pycnoporuscoccineus. Biotechnology for Biofuels, $8(1)$. http://dx.doi.org/10.1186/s13068-0150407-8.

Desjardin, D. E., Wood, M., \& Stevens, F. A. 2015. California mushrooms: The comprehensive identification guide.Portland: Oregon.

Fazio, F., Lionetto, L., Molinaro, G., Bertrand, H. O., Acher, F., Ngomba, R. T.,Goudet, C. 2012. Cinnabarinic Acid, an Endogenous Metabolite of the Kynurenine Pathway, Activates Type 4 Metabotropic Glutamate Receptors. Molecular Pharmacology, 81(5), 643656.

http://dx.doi.org/10.1124/mol.111.07476 $\underline{5}$.

Fitra, M. A., Thomy, Z., Samingan, Harnelly, E., \& Kusuma, H. I. 2020. The potency of mushrooms as food alternative in the forest park of PocutMeurahIntan, Saree, Aceh Besar. IOP Conference Series: Earth and Environmental Science,425, 012058. http://dx.doi.org/10.1088/1755$\underline{1315 / 425 / 1 / 012058}$. 
Quagga: Jurnal Pendidikan dan Biologi

Volume 13, Nomor1, Januari 2021, pp.48-59

Gierczyk, B., Rodriguez-Flakus, P., Pietras, M., Gryc, M., Czerniawski, W., \&Piątek, M. 2017. Coprinopsisrugosomagnispora: a distinct new coprinoid species from Poland (Central Europe). Plant Systematics and Evolution, 303(7), 915925. http://dx.doi.org/10.1007/s00606017-1418-7.

Habtemariam, S., 2019. The Chemistry, Pharmacology and Therapeutic Potential of the Edible Mushroom Dictyophoraindusiata (Vent ex. Pers.) Fischer (Synn. Phallus indusiatus). Biomedicines, $\quad 7(4), \quad 98$. http://dx.doi.org/10.3390/biomedicines70 40098.

Hawksworth, D.L. 2001. The magnitude of fungal diversity: the 1.5 million species estimate revisited. Mycological Research, 105(12),14221432.http://dx.doi.org/10.1017/s0953756 201004725 .

Heleno, S. A., Ferreira, I. C. F. R., Ćirić, A., Glamočlija, J., Martins, A., Queiroz, M. J. R. P., \&Soković, M. 2014. Coprinopsisatramentaria extract, its organic acids, and synthesized glucuronated and methylated derivatives as antibacterial and antifungal agents. Food Funct, 5(10), 2521-2528. http://dx.doi.org/10.1039/c4fo00490f.

Hibbett, D.S., Binder, M., Bischoff, J.F., Blackwel,1 M., Cannon, P.F., et al. 2007. A higher-level phylogenetic classification of the Fungi. Mycol Res. 111(Pt5):509-47. doi: 10.1016/j.mycres.2007.03.004.

Iramayana, I., Taskirawati, I. \&Arif, A. 2019. Keragamanjamur pada log dan kayugergajiannyatoh (Palaquiumsp). Perennial, $15(1), \quad 8$. http://dx.doi.org/10.24259/perennial.v15i 1.6729 .

Khastini, R. O., Wahyuni, I., Lista, L., \&Saraswati, I. 2019. Inventory and utilization of macrofungi species for food in Cikartawana inner Baduy Banten. Biodidaktika, jurnalbiologi dan pembelajarannya. 14(1), 7-13. http://dx.doi.org/10.30870/biodidaktika. v14i1.4838.

Khastini, R.O., Wahyuni, I. \&Saraswati, I.2018. Ethnomycology of Bracket
p-ISSN 1907-3089, e-ISSN2651-5869

https://journal.uniku.ac.id/index.php/quagga

Fungi in Baduy Tribe Indonesia. Biosaintifika: Journal of Biology \& Biology Education, 10(2), 424-432. http://dx.doi.org/10.15294/biosaintifika. v10i2.14082.

Kumar, M., Ali, S., Lal, S., Sinha, M. 2019. Anti-pathogenic efficacy of Indian edible

macrofungiDacryopinaxspathularia (Schwein) and Schizophyllum commune (Fries) against some human pathogenic bacteriae. 06. 10.1729/Journal.19493.

LIPI. 2019. Status keanekaragaman hayati Indonesia : kekayaan jenis tumbuhan dan jamur Indonesia. Ed : Retnowati A, Rugayah, Rahajoe JS, Arifiani D. Jakarta : LIPI Press.

Muñoz, G., Caballero, A., Contu, M., \&Vizzini, A. 2012. Anew Leucoagaricus species of section Piloselli (Agaricales, Agaricaceae) from Spain. IMA Fungus, 3(2), 117123.

http://dx.doi.org/10.5598/imafungus. 2012.03.02.03.

Ning, Y.J., Wang, S.S., Chen, Q.J., Ling, Z.R., Wang, S.N., Wang, W.P.,Zhu, M.J. 2016. An extracellular yellow laccase with potent dye decolorizing ability from the fungus Leucoagaricusnaucinus LAC04. International Journal of Biological Macromolecules, 93, 837-842. http://dx.doi.org/10.1016/j.ijbiomac.2016 .09 .046 .

Prayudi, D. P., Kurniawati, J., Mutiarani, Y. P., Salim, I., \&Aminatun, T. 2019. Considering Sampling Methods for Macrofungi Exploration in Turgo Tropical Forest Ecosystem. Journal of Tropical Biodiversity and Biotechnology, 4(1), 1. http://dx.doi.org/10.22146/jtbb.38381.

Putra, I.P. 2020b. CatatanBeberapaJamur Makro di PulauBelitong :Deskripsi dan Potensinya Note on Macro Fungi on Belitong Island: Description and Potential.Bioeduscience, $4(1), \quad 11-$ 20.https://doi.org/10.29405/j.bes/4111204416.

Putra, I.P. 2020c. Komunikasisingkat :laporankeberadaanjamurberacunPodost roma ef. cornu-damaedariluar Bogor di 
Indonesia. Jurnal Konservasi Hayati,

$16(2)$,

$65-70$.

https://doi.org/10.33369/hayati.v16i2.12 408.

Putra, I.P. 2020d. Kasus keracunan Inocybesp. di Indonesia. Prosiding Seminar Nasional Biologi Di Era Pandemi Covid 19. JurusanBiologi, Fakultas Sains dan Teknologi, Universitas Islam Negeri (UIN) Alauddin Makassar.

Putra, I.P., \&Hafazallah, K. 2020. CatatanKomunitasPemburuJamur

Indonesia: Kolaborasi Lintas Profesi dan

GenerasiMengenaiEtnomikologiJamurJamur Indonesia. Sukabumi: Haura Publishing.

Putra, I.P., Amelya, M.P., Nugara, N.H., Zamia, H.Z. 2019b. Notes of Some Macroscopic Fungi at IPB University Campus Forest: Diversity and Potency. Biota, 12(2), 57-71. https://doi.org/10.20414/jb.v12i2.192.

Putra, I.P., Mardiyah, E., Amalia, N.S., Mountara, A. 2017. Ragamjamurasalserasah dan tanah di Taman Nasional Ujung KulonIndonesia.JurnalSumberdaya

Hayati,3(1), $1-$

7.https://journal.ipb.ac.id/index.php/su mberdayahayati/article/view/24679/160 $\underline{81 .}$

Putra, I.P., Nasrullah, M.A., Dinindaputri, T.A. 2019a. Study on Diversity and Potency of Some Macro Mushroom at GunungGedePangrango National Park. Buletin Plasma Nutfah, 25(2), 1-14. http://dx.doi.org/10.21082/blpn.v25n2.2 019.p1-14.

Putra, I.P., Sitompul, R., Chalisya, N. 2018. Ragam Dan PotensiJamur Makro Asal Taman WisataMekarsariJawaBarat.AlKauniyah: JurnalBiologi, 11(2),133150.

http://dx.doi.org/10.15408/kauniyah.v1 $1 \mathrm{i} 2.6729$.

Putra, I.P.2020a. Record On Macroscopic Fungi At IPB University Campus Forest : Description And Potential Utilization. IJOSE, $4(1): 1-$

11.DOI: $\underline{10.31002 / \text { ijose.v4i1.2180 }}$

Retnowati, A.2018. The species of Marasmiellus (Agaricales:
Omphalotaceae) from Java and Bali. Gardens' Bulletin Singapore, 70(1), 191-258.

http://dx.doi.org/10.26492/gbs70(1).201 8-17.

Ribeiro, J.P., Ali Abol Hassan, M., Rouf, R., Tiralongo, E., May, T.W., Day, C.J., Imberty, A., Tiralongo, J. and Varrot, A. 2017. Biophysical characterization and structural determination of the potent

cytotoxic Psathyrellaasperospora lectin . Proteins, 85: 969-975. doi:10.1002/prot.25265.

Rokuya, I., Yoshio, O., Tsugia, H. 2011. Fungi of Japan. Japan: YamaKeiPublishers.

Sękara, A., Kalisz, A., Grabowska, A.,Siwulski, M. 2015. Auricularia spp. - mushrooms as Novel Food and therapeutic agents - a review. Sydowia Horn. $67.1-10$. 10.12905/0380.sydowia67-2015-0001.

Sevindik, M., Rasul, A., Hussain, G., Anwar, H., Zahoor, M. K., Sarfraz, I., Kamran, K. S., Akgul, H., Akata, I., \&Selamoglu, Z. 2018. Determination of anti-oxidative, anti-microbial activity and heavy metal contents of Leucoagaricusleucothites. Pakistan journal of pharmaceutical sciences, 31(5), 2163-2168.

Sicoli, G., Passalacqua, N. G., De Giuseppe, A. B., Palermo, A. M., \& Pellegrino, G. 2019. A new species of Psathyrella (Psathyrellaceae, Agaricales) from Italy. MycoKeys, 52, 89-102. http://dx.doi.org/10.3897/mycokeys.52. 31415.

Téllez-Téllez, M., 2016. Mycosphere Essay 11: Fungi of Pycnoporus: morphological and molecular identification, worldwide distribution and biotechnological potential. Mycosphere, 7(10), 1500-1525. http://dx.doi.org/10.5943/mycosphere/si $/ 3 \mathrm{~b} / 3$.

Vellinga, E.C. 2004. Genera in the family Agaricaceae: evidence from nrITS and nrLSU sequences. Mycological Research, 108(4),354-377. 